ENTREPRENEURSHIP AND SUSTAINABILITY ISSUES

ISSN 2345-0282 (online) http://jssidoi.org/jesi/

2020 Volume 8 Number 2 (December)

http://doi.org/10.9770/jesi.2020.8.2(20)
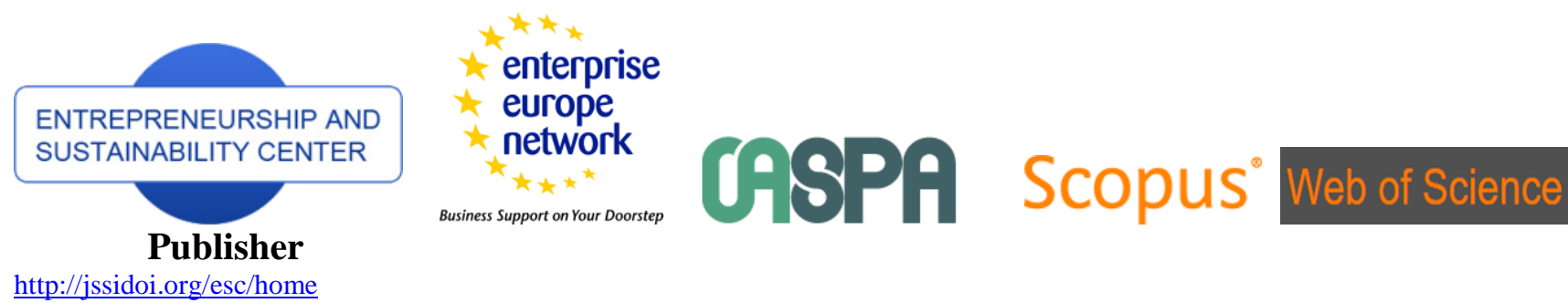

http://jssidoi.org/esc/home

\title{
ECO-ORIENTED CULTURE AND FINANCIAL PERFORMANCE: ROLES OF INNOVATION STRATEGY AND ECO-ORIENTED CONTINUOUS IMPROVEMENT IN MANUFACTURING STATE-OWNED ENTERPRISES, INDONESIA
}

\author{
Noorlailie Soewarno ${ }^{1}$, Bambang Tjahjadi ${ }^{2 *}$ \\ ${ }^{1,2}$ Faculty of Economics and Business, Universitas Airlangga, Surabaya, Indonesia \\ E-mails: ${ }^{1}$ noorlailie-s@feb.unair.ac.id; ${ }^{2 *}$ bambang.tjahjadi@feb.unair.ac.id (coressponding author)
}

Received 15 March 2020; accepted 15 August 2020; published 30 December 2020

\begin{abstract}
This study focuses on investigating the mediating effect of innovation strategy and eco-oriented continuous improvement on the relationship between eco-oriented culture and corporate financial performance. This study provides empirical evidence to the resourcebased theory stating that a corporate needs to have valuable, rare, inimmitable, and nonsubstitutable resources to remain competitive. Organization culture, innovation and continuous improvement capabilities are considered as the critical resources that must be developed by a corporate to gain competitive advantage. This study is designed as quantitative research using a variance-based or the partial least square structural equation modeling (PLS-SEM). Study on 103 managers of the manufacturing state-owned enterprises (SOEs) in Indonesia reveals that innovation strategy and eco-oriented continuous improvement partially mediate the relationship between EOC and corporate financial performance. This study contribute to provide greater understanding regarding the need to consider eco-orientation within a corporate life. It implies that for boosting the corporate financial performance, a corporate needs to adapt the eco-orientation and understand the mechanism on how eco-oriented culture affects corporate financial performance using innovation strategy and continuous improvements in eco-oriented operation management processes, customer management processes, innovation management processes, as well as regulatory and social processes. A strong eco-oriented culture will lead to beneficial innovations and eco-oriented continuous improvement; hence it has a positive association to financial performance. Many studies have been conducted on how a culture affects financial performance. However, there are still few studies describing the mechanism of how a culture can improve financial performance using innovation strategy and eco-oriented continuous improvement, especially in the context of environmental issues and in a developing country. Focusing on explaining the mediating effect, this study employs a more comprehensive structural model integrating four ecooriented variables.
\end{abstract}

Keywords: eco-oriented culture; innovation strategy; eco-oriented continuous; improvement and corporate financial performance

Reference to this paper should be made as follows: Soewarno, N., Tjahjadi, B. 2020. Eco-oriented culture and financial performance: roles of innovation strategy and eco-oriented continuous improvement in manufacturing state-owned enterprises, Indonesia. Entrepreneurship and Sustainability Issues, 8(2), 341-359. http://doi.org/10.9770/jesi.2020.8.2(20)

JEL Classifications: O1, M11, M14

Additional disciplines: ecology and environment 


\section{ENTREPRENEURSHIP AND SUSTAINABILITY ISSUES}

ISSN 2345-0282 (online) http://jssidoi.org/jesi/

2020 Volume 8 Number 2 (December)

http://doi.org/10.9770/jesi.2020.8.2(20)

Make your research more visible, join the Twitter account of ENTREPRENEURSHIP AND SUSTAINABILITY ISSUES: @Entrepr69728810

\section{Introduction}

A growing number of governments around the world are strengthening their environmental laws and regulations because the environment affects economic development as well as the societies' quality of life. In Indonesia, for example, the Government of Indonesia (GOI) protects the environment using both national and regional level regulations to decrease the rate of emissions to $29 \%-41 \%$ by 2030 to meet the international agreements (Alisjahbana and Busc, 2017). Indonesia as an archipelago consisting of more than 17,000 islands and home to about 267 million people is still facing significant environmental problems. It is believed that Indonesia is the world's second-largest contributor of plastic pollutants in the oceans, after China (Indonesia Investment, 2019). In term of forest degradation, Indonesia is the third largest area of tropical forest degradation after Brazil and Congo and has contributed to environmental issues for years. Indonesia has surpassed Brazil as a tropical country with the highest levels of deforestation (Margono et al., 2014). A study by Turubanova et al. (2018) confirmed that given high rates of loss for comparatively low remaining forest area, Indonesia exhibits greater pressure on remnant primary forests than either Brazil or Congo.

Longstanding debates have also been done between protection for environmental sustainability and the production of valuable commodities (McCarthy and Kathryn, 2016). Several studies have examined the relation between economic growth and environmental degradation. A number of empirical papers find evidence of an inverted between pollution levels rise and income rising (Tamazian and Rao, 2010). Many facets of manufacturing business process have importat implications for natural environment. Design of product, selection of raw materials, operation of manufacturing process, delivary of product or service, and availability of reuse and recycle for spent products have been a big issue of environmental degradation (Ahmed et al., 1998; Klassen, 2006).

Management of firms needs to pay more attention on these rapidly growing environmental issues by building organizational culture, developing innovations in products and programs as well as improving environmentallyrelated business processes. Most post-modern managers are well aware that sustainability is the today's business goal (Kim and Lee, 2012; Soewarno et al., 2018). No doubt, post-modern firms are required to successfully deal with and keep innovating on the environmental issues to gain sustainable competitive advantage. Green innovation becomes strategically important from time to time.

Modern societies changed dramatically compared to the past (Chitsaz et al., 2019). In post-modernism sustainability is meant for everyone. It tries to involve all people, whether quantitative growth or qualitative development supporters, to work for those causes in which their interests overlap. The relativism of sustainability gives many opportunities for cooperation between the sustainable growth and sustainable development supporters, but because of the polarized worldviews few of them can induce real change (Ketola, 2009).

Sustainability is translated into a "triple bottom line" responsibility, with the implication that the assessment of business results should be based not only on economic performance but also on the environmental and social impact as well (Sheth et al., 2011). Sustainable development and sustainability assessment are two issues that have been addressed by academe and practinioners including local government agencies, community members, as well as commercial and industrial planners (Sacirovic et al., 2018; Zhou, et al., 2018). Industrial symbiosis is defined as a collective approach to competitive advantage in which separate industries exchange materials, energy, water and/or by-products, plays an important role in the transition towards sustainable development (Chertow, 2000, Chertow, 2007). Industrial symbiosis resolves resource depletion problems, waste management 


\section{ENTREPRENEURSHIP AND SUSTAINABILITY ISSUES}

ISSN 2345-0282 (online) http://jssidoi.org/jesi/

2020 Volume 8 Number 2 (December)

http://doi.org/10.9770/jesi.2020.8.2(20)

Make your research more visible, join the Twitter account of ENTREPRENEURSHIP AND SUSTAINABILITY ISSUES: @Entrepr69728810

and pollution using waste streams to generate more value across industrial actors (Baldassarre et al., 2019; Chertow, 2007).

The research community has also paid increasing attention to the environment as compared to other aspects of sustainability (Ferreira et al., 2016). Until recently, sustainable development was perceived as an essentially environmental issue, concerning the integration of environmental concerns into economic decision-making (Lehtonen, 2004). Wernerfelt (1984) in the Resource-Based View (RBV) stated that a firm is a bundle of resources, and the way that they are combined enables firms to have a competitive advantage among others. Resource-based view (RBV) is a managerial framework used to determine the strategic resources a firm can exploit to achieve sustainable competitive advantage. Business process, strategy and organization culture are also part of resources that firms owned and used for achieving competitive advantage. The RBV concerns that those resources owned by firms must meet valuable, rare, inimitable and nonsubstitutable (VRIN) criteria (Nason and Wiklund, 2018).

The RBV as a theory is inpired by the work of Penrose (1959) arguing that resources are a source of competitive advantage. Hoopes et al. (2003) stated that the resources account for inter-firm performance differences. The RBV argues that the firm should be considered as a bundle of resources which is defined by Wernerfelt (1984) as anything which can provide the firm with a strength or weakness. These resources are also defined by Barney and Arikan (2001) as tangible and intangible assets which are used by the firm to formulate and implement strategies. In order to be a source of competitive advantage the resource should be valuable, rare, difficult to imitate it and no other resource which can substitute it (Nason and Wiklund, 2018).

Many studies have been conducted on the role of culture in relation to financial performance (Ogbonna and Harris, 2000; Melo, 2012; Nazarian et al. 2017; Rottig and Reus, 2018; Zhou et al., 2018). However, there are still few studies that explain the mechanism of how a culture can improve financial performance, especially in the context of environmental issues. Culture is also important in sustainability involvement among firms around the world as found in the study of Coulmont et al. (2018) which stated that firms in countries with high individualism or high masculinity rankings are more likely to affiliate with the UNGC (United Nations Global Compact). UNGC is an organization that align strategies and operations with universal principles on human rights, labour, environment and anti-corrupetion, and take actions that advance societal goals. Study results show that highly individualist societies (IDV) and high masculinity levels countries appear to be more affiliate with the UNGC. Individuals are less preoccupied and with social and environmental issues and have a boarder viewpoint (Cox et al., 2011; Husted, 2005). And masculinity levels have a positive impact on the UNGC affiliation to enhance their corporate image. These motivations are consistent with the values promoted by masculine society, which include competition, power acquisition, and especially recognition (Cetindamar and Husoy, 2007).

In the era of environmental awareness, eco-oriented culture must be the main habit of management and the focus of every strategy. A growing number of business leaders commits to create a better environment of the world by integrating eco-orientation to their corporate culture. Referring to the philosophy of strategy maps by Kaplan and Norton (2004), one of organizational capital owned by a company is its culture. Organizational culture that includes consideration of the environmental impacts in it is called eco-oriented culture (Kim and Lee, 2012). This culture will lead management of the company to formulate and execute their strategies, including innovation strategy.

In the most basic sense, strategy is the primary means for achieving competitive advantage and subsequent superior performance outcomes (Hansen et al., 2006; Olson et al., 2018). Innovation is a main strategic tool in 


\section{ENTREPRENEURSHIP AND SUSTAINABILITY ISSUES}

ISSN 2345-0282 (online) http://jssidoi.org/jesi/

2020 Volume 8 Number 2 (December)

http://doi.org/10.9770/jesi.2020.8.2(20)

Make your research more visible, join the Twitter account of ENTREPRENEURSHIP AND SUSTAINABILITY ISSUES: @Entrepr69728810

order to gain a competitive advantage in such complex environments (Akman and Yilmaz, 2008; Kwak et al., 2018). Also, innovation is a basic precondition for long-term success, growth, performance continuance and firms' survival (Akhlagh et al., 2013). Firms should be dedicated to investing in research and development, manufacturing innovative products and achieving substantial performance to be competitive (Karabulut, 2015). As an alternative to the role of innovation in competitive strategy, the value innovation methodology on strategy has been proposed by Kim and Mauborgne $(2005,2017)$ regarding how to create uncontested market space and making the competition irrelevant. Leavy (2017) explores how the value innovation strategy works in practice and how it has evolved since its introduction.

Innovation strategy that a firm uses to operate its business must be executed in excellent business processes that lead to customer satisfaction and improved financial performance. Mattera and Baena (2015) used the innovation theory in conjunction with the stakeholder theory to analyze a firm's intangible assets enhancement and found that corporate social responsibility (CSR) affects a firm's value-added in Spanish firms. A study by Chuan and Lin (2017) of 115 financial service firms in Taiwan revealed that technology, human and business resources are crucial in developing an e-service capability, and an innovation strategy positively influences organizational performance. Nowadays, as a global society evolves, innovation strategy appears to be an evolutionary process at work, resulting in the progression of organizational philosophies from the industrial-focused production orientation to the human-focused eco-orientation (Miles and Munilla, 1993). Production activity that has an impact on ecological sustainability had been monitored and controled by government to minimize environmental damage. Environmental concerns have thus impacted manufacturing firms' innovation (Wang \& Wang, 2019). Hence firms may adopt an eco-orientation as a strategic competitive advantage, for instance eco-oriented corporate culture and eco-oriented continuous improvement which will be investigated in this study.

Each company has differences in integrating environmental aspects into its daily operations, including building an eco-oriented culture, innovating on eco-oriented products for business processes to achieve better financial performance. Porter, Sheehan and Foss (2009) stated that the activity is the smallest unit of a strategy. The integration of the activity-based and resource-based views provides a comprehensive explanation of how a firm creates value. Therefore, innovation strategy must be reflected in the daily activities of the company's internal business processes including eco-oriented continuous improvements in operations management processes, customer management processes and innovation management processes as well as regulatory and social processes.

The objective of this study is to analyze and empirically test the mechanism of how an eco-oriented culture affects financial performance using innovation strategy and eco-oriented continuous improvement. This study uses a more comprehensive model to examine the mediating effects instead of the direct effects among variables and it investigates the issue of eco-orientation which becomes a trend in the world.

The main contribution of this study is to provide empirical evidence and a more comprehensive understanding of activity-based and resource-based views, especially the mechanism of how a culture affects financial performance in the era of environmental awareness. This study also provides evidence on how managers in a developing country perceive the importance of managing environmental issue in their companies. The study also addresses practical implications and suggestions for policy-making either in a company or a government institution.

Based on the previous discussions, this study has three research questions as follows:

RQ1. Does eco-oriented continuous improvement mediate the relationship between innovation strategy and corporate financial performance? 


\section{ENTREPRENEURSHIP AND SUSTAINABILITY ISSUES}

ISSN 2345-0282 (online) http://jssidoi.org/jesi/

2020 Volume 8 Number 2 (December)

http://doi.org/10.9770/jesi.2020.8.2(20)

Make your research more visible, join the Twitter account of ENTREPRENEURSHIP AND SUSTAINABILITY ISSUES: @Entrepr69728810

RQ2. Does eco-oriented continuous improvement mediate the relationship between eco-oriented culture and corporate financial performance?

RQ3. Do eco-oriented continuous improvement and innovation strategy mediate the relationship between ecooriented culture and corporate financial performance?

\section{Literature Review and Hypotheses Development}

\subsection{Eco-oriented Culture, Eco-oriented Continuous Improvement and Corporate Financial Performance}

Jabnoun (2001) stated that the success of continuous improvement initiatives is dependent on many factors that include leadership, structure and shared organizational values. Continous improvement not only refers on changes in managerial activities but it also must be followed by improvements in term of knowledge transfer from owner to employee and senior workers (Herlina et al., 2019). It means that corporate culture can be one of the antecedents of continuous improvement. Culture plays a strategic role in business process improvements. Zehir et al. (2011) found that leadership and organizational culture affect business performance outcomes of firms in Istanbul, Turkey. An empirical study on the role of culture by Chatterjee et al. (2018) also confirmed that flexible organizations (predominantly clan and/or adhocracy cultures) have a more supportive learning transfer environment than stable organizations (predominantly market and/or hierarchy cultures). Stone, Joseph, \& Blodgett, (2004) indicating that an organization's ability to develop an eco-oriented corporate culture is related to several factors, which are top management emphasis, management risk aversion, rewards and incentives, local community concerns, organizational connectedness, and industry regulatory climate. Meanwhile Kim and Lee, (2012) find that Stakeholder Pressure can influence the adoption of environmental logistics practices (ELP) to build a unique Eco-Oriented Culture. Continuous improvements will have a good impact on financial performance. This is supported by Chen (2018) stating that a better management of supply chain risks has affected corporate financial performance. Eco-oriented continuous improvement in development, sourcing, manufacturing and transportation activities needs one policies to find solutions for company's environmental issues. Furthermore, this improvement will increase company's efficiency and enhance their revenue opportunity (Orsato, 2009). The first hypothesis is based on logically thinking that the organizational culture focusing on ecoorientation will positively drive eco-oriented continuous improvement which will then enhance corporate financial performance. Therefore, the following first hypothesis is proposed:

$\mathrm{H}_{1}$ : Eco-oriented continuous improvement mediates the relationship between eco-oriented culture and corporate financial performance

\subsection{Innovation Strategy, Eco-oriented Continuous Improvement, and Corporate Financial Performance}

Scholars have provided empirical evidence that innovation strategy determines the success in innovations and continuous performance improvements, and that it will also have a positive impact on financial performance. A study by Yasar et al. (2017) showed a mediating effect of continuous improvement on innovation-financial performance relationship in 384 companies of Turkish manufacturing companies. Karabulut (2015) demonstrated that the innovation strategy of Turkish manufacturing firms leads them to improve their financial performance. Nybakk and Jenssen (2012) also found that innovation strategy enhances financial performance. Chuan and Lin (2017) proved that an innovation strategy positively influences organizational performance of 115 financial service firms in Taiwan. Pogodina et al. (2019) explained that innovation activity increases efficiency in industrial companies which are largely determined by the level of their innovation and marketing potential. However, Nybakk et al. (2011) stated that the model of innovation strategy and climate for innovation accounts for only $16 \%$ of the variation in firm performance. It means that innovation strategy becomes an antecedent only if it is moderated or mediated by other factors. Thus, when a company adopts the innovation strategy with the focus of 
ENTREPRENEURSHIP AND SUSTAINABILITY ISSUES

ISSN 2345-0282 (online) http://jssidoi.org/jesi/

2020 Volume 8 Number 2 (December)

http://doi.org/10.9770/jesi.2020.8.2(20)

Make your research more visible, join the Twitter account of ENTREPRENEURSHIP AND SUSTAINABILITY ISSUES: @Entrepr69728810

the environmental aspect, it is proposed that this strategy must be expressed in the daily operations or business processes which must be also continuously improved in order to meet the requirements of changing market. A better adaptation to an eco-oriented market will certainly lead to a better financial performance (Kwon \& Lee, 2019). For this reasoning, the following second hypothesis is:

H2: Eco-oriented continuous improvement mediates the relationship between innovation strategy and corporate financial performance.

\subsection{Eco-oriented Culture, Innovation Strategy, Eco-oriented Continuous Improvement and Corporate Financial Performance}

As previously stated, culture affects innovation. An exploratory study by Kaasa (2017) revealed the effects of different cultural dimensions on different innovation indicators covering many EU countries and neighbouring countries and confirmed that innovation processes are strongly reliant on culture. A study by Rafailidis et al. (2017) on 480 Greek mid-to-high technology and Small and Medium Enterprises confirmed that quality mediates the relationship between cultural ambidexterity and innovation performance. Prim et al. (2017) also proved that cultural dimensions associate with the degree of innovation at the national level.

The linkage between innovation strategy and continuous improvement is reflected in the interview report conducted by Bapst (1994) which stated that the process of innovation development, especially the early part of the development process, must be systematically analyzed and continuously improved to reduce the repeated same mistakes. Moreover, Calantone, et al. (2002) stated that a positive learning climate is beneficial for firms that aspire to stand out through product development, and new product development requires continuous organizational renewal. It can be concluded that to achieve a better firm's performance, managers who adopt innovation strategy need to implement learning activities which reflect the continuous improvements in their organization. Hence, the third hypothesis is formulated based on the following logical thinking. If a company has adopted a strong eco-oriented culture and wants to improve their financial performance, then the company must execute it in their daily operations by implementing innovation strategy and eco-oriented continuous improvement. To test the logical linkage among eco-oriented culture, innovation strategy, eco-oriented continuous improvement and corporate financial performance, the following third hypothesis is proposed:

H3: Eco-oriented continuous improvement and innovation strategy mediate the relationship between eco-oriented culture and corporate financial performance.

\section{Research Model}

This study has four variables, namely Corporate Financial Performance (CFP) as a dependent variable, Innovation Strategy (IST) and Eco-oriented Continuous Improvement (ECI) as mediating variables, and Eco-oriented Culture (EOC) as an independent variable. The relationship among those variables is presented in a research model in Figure 1. 


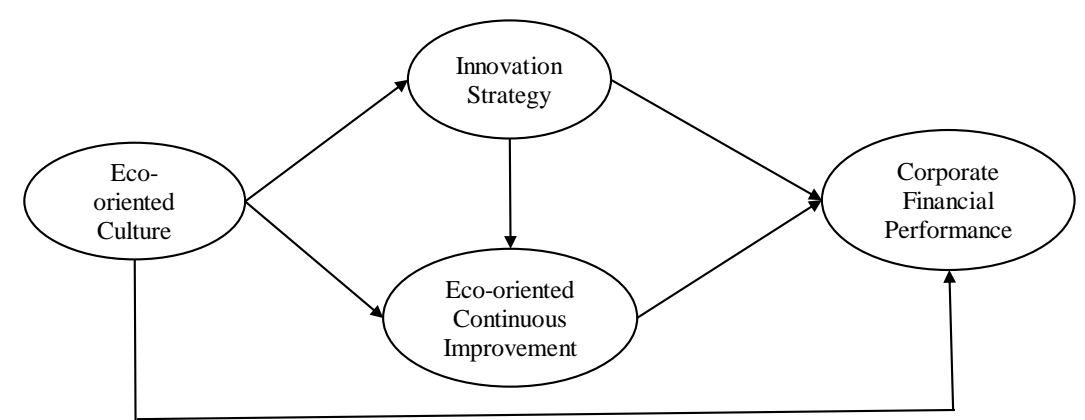

Fig.1. Research model

\subsection{Research setting and sample}

This study derived a sample from 200 managers of the SOEs in Indonesia with the status of "perseroan terbatas" or a limited liability company. There are 101 SOEs and the number of the manufacturing subsidiaries is unknown due to limited access. Indonesia was chosen in this study because environmental issues are still a major problem, such as plastic waste, forest fire haze, factory pollution and other issues that require a change in culture and management mindset. The state-owned enterprises (SOEs) were chosen because they play a significant role along with large private conglomerates in the Indonesian economy (see Appendix). However, the study focuses only on the SOEs. Questionnaires with a covering letter describing the objective of the study and confidentiality assurance were distributed to every corporate secretary of the SOEs, with a request to distribute to the managers in the company and the manufacturing subsidiaries. As many as 104 managers participated and returned the questionnaires. Only 1 questionnaire was not properly completed, yielding a total of 103 usable responses. Therefore the effective response rate was $51.5 \%$. Table 1 shows the types of industry and the number of participated managers.

Table 1. Type of Industry and Participated Managers

\begin{tabular}{|c|l|c|}
\hline \multicolumn{1}{|c|}{ Industry } & \multicolumn{1}{|c|}{$\begin{array}{c}\text { Participated } \\
\text { Managers }\end{array}$} \\
\hline 1. & Heavy equipment & 8 \\
\hline 2. & Nuclear power & 3 \\
\hline 3. & Industrial machinery & 9 \\
\hline 4. & Pharmaceutical & 10 \\
\hline 5. & Explosives & 2 \\
\hline 6. & Ship & 7 \\
\hline 7. & Salt producer & 12 \\
\hline 8. & Glass producer & 13 \\
\hline 9. & Fertilizer & 11 \\
\hline 10. & Fabric manufacturer & 13 \\
\hline 11. & Steel & 12 \\
\hline 12. & Cement & 3 \\
\hline & \multicolumn{1}{c}{ TOTAL } & $\mathbf{1 0 3}$ \\
\hline
\end{tabular}




\section{ENTREPRENEURSHIP AND SUSTAINABILITY ISSUES}

ISSN 2345-0282 (online) http://jssidoi.org/jesi/

2020 Volume 8 Number 2 (December)

http://doi.org/10.9770/jesi.2020.8.2(20)

Make your research more visible, join the Twitter account of ENTREPRENEURSHIP AND SUSTAINABILITY ISSUES: @Entrepr69728810

\subsection{Analytical Technique}

This study employed a variance-based or partial least square (PLS) stuctural equation modeling to test the hypotheses, The PLS was considered suitable for this study for the following reasons. Firstly, it can handle multiple dependent and independent variables simultaneously (Chin, 1998a, 1998b). Secondly, it can deal with small sample sizes and multicollinearity among independent variables (Nitzl, 2016). Thirdly, it does not require a normal distributional assumption (Chin, 1998; Chin and Newsted, 1999).

\subsection{Instruments}

\subsubsection{Corporate Financial Performance}

Corporate financial performance is operationally defined as the perception of a manager regarding the four financial perspectives as in the strategy maps created by Kaplan \& Norton (2004), namely improve cost structure, increase asset utilization, expand revenue opportunities and enhance customer value. Among those four perspectives, only two perspectives were used to provide the measurements for this indicator, namely increase asset utilization and expanding revenue opportunities for the following reasons. Firstly, Increasing asset utilization closely relates to improving cost structure. This means that when asset utilization increases, then costs will be reduced. Secondly, expanding revenue opportunities also closely relates to enhancing costumer value. This means that customer value will be increased when a company creates more opportunities to sell products to customers. It was measured by using a questionnaire with a 6-point Likert scale which is used to avoid central tendency bias. This concept is regarded as the model which is appropriate for measurement (Chang, 1993). With use of this scale, the respondents cannot choose the moderate value, middle point in this kind of rating scale, the respondents have to consider the answer for a while. Chen, Lee, \& Stevenson (1995) found that Japanese and Chinese were more likely to choose the midpoint of a Likert scale item than Americans, but we found this effect only for items involving expression of positive feelings. We made a conclusion that Asians with likely the same cultural collectivism groups as Japan and Chinese, has the same way to respond Likert Scale using mid-point. That is the reason why this research used 6-Point Likert Scale.

\subsubsection{Eco-oriented Continuous Improvement}

Eco-oriented continuous improvement is operationally defined as the perception of a manager regarding continuous improvement considering eco-orientation during 2015 to 2017 . It was measured with a four-itemquestionnaire adapted from Lee (2004) using a 6-point Likert scale, but with some modifications to measure the eco-orientation.

\subsubsection{Innovation Strategy}

Innovation strategy is operationally defined as the perception of a manager regarding innovation strategy she/he has formulated during 2015 to 2017. It was measured using a questionnaire adapted from Akman and Yilmaz (2008) with a 6-point Likert scale. This instruments used Venkatraman's typology (1989) which defined innovation strategy as composed of six dimensions, namely aggressiveness, analysis, defensiveness, futurity, proactiveness and riskiness. For this study, only four dimensions were used, excluding aggressiveness and analysis due to practicality reasons. Both aggressiveness and analysis are not used in this study because they do not fit the character of SOEs management which should not act aggressively and tend to be excessively bureaucratic.

\subsubsection{Eco-oriented Culture}

Eco-oriented culture is operationally defined as the perception of a manager regarding her/his firm's culture which focuses on eco-orientation during the last three years. It was measured with the eco-orientation questionnaire adapted from Stone et al. (2004) using a 6-point Likert scale. 


\section{ENTREPRENEURSHIP AND SUSTAINABILITY ISSUES}

ISSN 2345-0282 (online) http://jssidoi.org/jesi/

2020 Volume 8 Number 2 (December)

http://doi.org/10.9770/jesi.2020.8.2(20)

Make your research more visible, join the Twitter account of ENTREPRENEURSHIP AND SUSTAINABILITY ISSUES: @Entrepr69728810

\section{Analysis and Results}

\subsection{Descriptive Statistics}

Table 2 presents the results of the descriptive statistics of variables. It shows both theoretical and actual as well as minimum and maximum scores of responses, mean and the standard deviation. Although there is a wide range of responses, the mean values show that the managers tended to have a strong commitment to their corporate financial performance (5.06). They believed that their company implements eco-oriented continuous improvement (5.04) in their daily operations. The less highly rated eco-oriented culture (4.69) and innovation strategy (4.77) reflect that the state-owned enterprises in Indonesia have not yet become concerned with eco-oriented culture and innovation strategy.

Table 2. Results of descriptive statistics

\begin{tabular}{|l|c|c|c|c|c|c|}
\hline \multirow{2}{*}{ Variable } & \multicolumn{2}{|c|}{ Theoretical Score } & \multicolumn{2}{c|}{ Actual Score } & \multirow{2}{*}{ Mean } & \multirow{2}{*}{ SD } \\
\cline { 2 - 7 } & Min & Max & Min & Max & & \\
\hline Eco-oriented Culture (EOC) & 1 & 6 & 3 & 6 & 4.69 & 0.58 \\
\hline Innovation Strategy (IST) & 1 & 6 & 2 & 6 & 4.77 & 0.95 \\
\hline Eco-oriented Continuous Improvement (ECI) & 1 & 6 & 3.25 & 6 & 5.04 & 0.66 \\
\hline Corporate Financial Performance (CFP) & 1 & 6 & 3 & 6 & 5.06 & 0.75 \\
\hline
\end{tabular}

The focus of this study is to empirically prove the relationships among variables studied using a more comprehensive model. Therefore, this study employed a structural equation modeling for analytical method. The research hypotheses were tested using a variance-based application package which is commonly used and is suitable for social research (Hair, Risher, Sarstedt, \& Ringle, 2018). The PLS structural equation modeling is a technique which simultaneously examines both measurement and structural models. The measurement model specifies the relationship between the measures and the latent variables or constructs. It also assesses the reliability and validity of measures relating to specific constructs. The structural model identifies the relationships among constructs (Chin, 1998b).

\subsection{Measurement model analysis}

The objective of the measurement model analysis is to evaluate the relationship between measures and constructs so that the reliability and validity of measures relating to specific constructs can be assessed. Table 2 shows that all measures are significant and above the 0.60 loading level. Chin (1998a, 1998b) stated that loading factors should be at least 0.60 meaning that the measure is accounting for at least 60 percent of the variance of the underlying latent variable. The cut-off point of 0.60 shows that the measures share more variance with their respective constructs than with the error variance. Furthermore, Table 3 shows the composite reliability coefficients for the constructs are all above the accepted level of 0.70 as stated by Nunnaly (1967).

The construct validity consists of convergent validity and discriminant validity. The average variance extracted (AVE) was employed to assess convergent validity in this study. According to Hulland (1999), a construct should have an AVE measure of 0.50 or more to be considered as having adequate convergent validity. Table 3 reveals that the AVEs for all the constructs are above 0.50 , and this provides evidence of convergent validity. 
Make your research more visible, join the Twitter account of ENTREPRENEURSHIP AND SUSTAINABILITY ISSUES: @Entrepr69728810

Table 3. Results of reliability and convergent validity

\begin{tabular}{|c|c|c|}
\hline Latent Variable & Loading & P Value \\
\hline \multicolumn{3}{|c|}{ Eco-oriented Culture $($ Composite Reliability $=0.815 ; \mathrm{AVE}=0.594)$} \\
\hline EOC 1 & 0.765 & $<0.001$ \\
\hline EOC 2 & 0.779 & $<0.001$ \\
\hline EOC 3 & 0.769 & $<0.001$ \\
\hline \multicolumn{3}{|c|}{ Innovation Strategy $($ Composite Reliability $=0.953 ; \mathrm{AVE}=0.834)$} \\
\hline IST 1 & 0.906 & $<0.001$ \\
\hline IST 2 & 0.906 & $<0.001$ \\
\hline IST 3 & 0.913 & $<0.001$ \\
\hline IST 4 & 0.929 & $<0.001$ \\
\hline \multicolumn{3}{|c|}{$\begin{array}{l}\text { Eco-oriented Continuous Improvement }(\text { Composite Reliability }=0.915 \text {; } \\
\text { AVE }=0.730)\end{array}$} \\
\hline ECI 1 & 0.873 & $<0.001$ \\
\hline ECI 2 & 0.86 & $<0.001$ \\
\hline ECI 3 & 0.807 & $<0.001$ \\
\hline ECI 4 & 0.877 & $<0.001$ \\
\hline \multicolumn{3}{|c|}{$\begin{array}{l}\text { Corporate Financial Performance }(\text { Composite Reliability }=0.913 \text {; } \\
\text { AVE }=0.840)\end{array}$} \\
\hline CFP 1 & 0.917 & $<0.001$ \\
\hline CFP 2 & 0.917 & $<0.001$ \\
\hline
\end{tabular}

Table 4. Discriminant validity.

\begin{tabular}{|c|c|c|c|c|}
\hline & EOC & IST & ECI & CFP \\
\hline EOC & $\mathbf{0 . 7 7 1}$ & & & \\
\hline IST & $0.396 * * *$ & $\mathbf{0 . 9 1 3}$ & & \\
\hline ECI & $0.365 *$ & $0.659 * * *$ & $\mathbf{0 . 8 5 5}$ & \\
\hline CFP & $0.365 *$ & $0.647 * * *$ & $0.65 * * *$ & $\mathbf{0 . 9 1 7}$ \\
\hline
\end{tabular}

*** Significant at $\mathrm{p}<0.01$

$*$ Significant at $\mathrm{p}<0.1$

Discriminant validity in this study is evaluated by comparing the square roots of AVEs with the correlation between constructs to describe whether a construct shares more variance with its measures than with other constructs (Fornell \& Larcker, 1981). It is valid when the square root of AVE of a construct is greater than the correlation between the construct with another construct. Table 4 shows correlation among constructs in the offdiagonal and the square root of AVE in the diagonal. Table 4 indicates adequate discriminant validity because the diagonal elements are all greater than their respective off-diagonal elements. In conclusion, it is demonstrated that the measurement model is reliable and valid. 


\section{ENTREPRENEURSHIP AND SUSTAINABILITY ISSUES}

ISSN 2345-0282 (online) http://jssidoi.org/jesi/

2020 Volume 8 Number 2 (December)

http://doi.org/10.9770/jesi.2020.8.2(20)

Make your research more visible, join the Twitter account of ENTREPRENEURSHIP AND SUSTAINABILITY ISSUES: @Entrepr69728810

Table 4 also shows positive significant correlations between eco-oriented culture and corporate financial performance $(r=0.365 ; p<0.1)$, innovation strategy $(r=0.396 ; p<0.01)$; eco-oriented continuous improvement $(r$ $=0.365 ; \mathrm{p}<0.1)$. These results suggest that eco-oriented culture is an important variable in improving innovation strategy, eco-oriented continuous improvement and corporate financial performance. In addition, there is a positive and significant relationship between innovation strategy and eco-oriented continuous improvement $(\mathrm{r}=$ 0.659; $\mathrm{p}<0.01)$ indicating that innovation strategy may improve eco-oriented continuous improvement.

\subsection{Structural model analysis}

The structural model is employed to test the hypotheses of this study. This model test is used to examine if the effect of eco-oriented culture on corporate financial performance is mediated by innovation strategy and ecooriented continuous improvement. In performing the structural model analysis the following two-step procedures (Baron and Kenny, 1986) were used. Firstly, a test for knowing if the eco-oriented culture affects corporate financial performance was conducted. Secondly, PLS was run for the full model by including innovation strategy and eco-oriented continuous improvement. Table 5 (Panel A) shows that before including mediating variables, eco-oriented culture is positively associated with corporate financial performance (path coefficient $=0.39$; $\mathrm{p}<0.01$ ). This result leads to further analysis by introducing the mediating variables of innovation strategy and eco-oriented continuous improvement.

Table 5 (Panel B and Panel C) shows the following results. First, the relationship between eco-oriented culture and eco-oriented continuous improvement is positive and significant (path coefficient $=0.125 ; \mathrm{p}=0.096<0.1$ ), and the relationship between eco-oriented continuous improvement and corporate financial performance is also positive and significant (path coefficient $=0.406 ; \mathrm{p}<0.001$ ). Therefore, hypothesis 1 stating that eco-oriented continuous improvement mediates the relationship between eco-oriented culture and corporate financial performance is supported (path of indirect effect $=0.051$; $\mathrm{p}$-value $=0.025<0.05$ ). Secondly, the relationship between innovation strategy and eco-oriented continuous improvement is positive and significant (path coefficient $=0.611 ; \mathrm{p}<0.001)$, and the relationship between eco-oriented continuous improvement and corporate financial performance is also positive and significant (path coefficient $=0.406 ; \mathrm{p}<0.001$ ). Therefore, the second hypothesis stating that eco-oriented continuous improvement mediates the relationship between innovation strategy and corporate financial performance is supported. Thirdly, the relationship between eco-oriented culture and innovation strategy is positive and significant (path coefficient $=0.412 ; \mathrm{p}<0.001$ ), innovation strategy and ecooriented continuous improvement is positive and significant (path coefficient $=0.125 ; \mathrm{p}=0.096$ ), and the relationship between eco-oriented continuous improvement and corporate financial performance is also significant (path coefficient $=0.406 ; \mathrm{p}<0.001$ ). Thus, the third hypothesis stating that eco-oriented continuous improvement and innovation strategy mediate the relationship between eco-oriented culture and corporate financial performance is also supported.

The direct effect of the relationship between eco-oriented culture and corporate performance before including mediating variables shows that the value of $\beta$ coefficient to be 0.39 with $p<0.01$. The direct effect of the relationship between eco-oriented culture and corporate performance after including mediating variables shows the smaller value of $\beta$ coefficient as 0.125 with still significant $p=0.097<0.1$. As argued by Baron and Kenny (1986), a full mediation exists if a significant direct effect of the independent variable and dependent variable becomes insignificant after controlling for the effects of the mediating variable. Also, Baron and Kenny (1986) claim that a partial mediation exists if the relationship between the independent variable and dependent variable remains significant after controlling for the effects of the mediating variable. This means that in this study, innovation strategy and eco-oriented continuous improvement partially mediate the relationship between ecooriented culture and corporate financial performance. 
ENTREPRENEURSHIP AND SUSTAINABILITY ISSUES

ISSN 2345-0282 (online) http://jssidoi.org/jesi/

2020 Volume 8 Number 2 (December)

http://doi.org/10.9770/jesi.2020.8.2(20)

Make your research more visible, join the Twitter account of ENTREPRENEURSHIP AND SUSTAINABILITY ISSUES: @Entrepr69728810

Table 5. PLS results of path coefficients

\begin{tabular}{|c|c|c|c|}
\hline PANEL A: & $\beta$ Coefficient & Probability & $\begin{array}{c}\begin{array}{c}\mathbf{R}^{2} \text { Coefficient } \\
\text { of }\end{array} \\
\text { Determination } \\
\end{array}$ \\
\hline \multicolumn{4}{|c|}{ Before including mediating variables } \\
\hline \multicolumn{4}{|l|}{ Direct Effect } \\
\hline $\mathrm{EOC}>\mathrm{CFP}$ & 0.39 & $\mathrm{p}<0.01$ & 0.15 \\
\hline PANEL B: & $\beta$ Coefficient & Probability & $\begin{array}{c}\begin{array}{c}\mathbf{R}^{2} \text { Coefficient } \\
\text { of } \\
\text { Determination }\end{array} \\
\end{array}$ \\
\hline \multicolumn{4}{|c|}{ After including mediating variables } \\
\hline \multicolumn{4}{|l|}{ Direct Effect } \\
\hline $\mathrm{EOC}>\mathrm{CFP}$ & 0.125 & $\mathrm{p}<0.1$ & 0.53 \\
\hline EOC > IST & 0.412 & $\mathrm{p}<0.001$ & 0.17 \\
\hline $\mathrm{EOC}>\mathrm{ECI}$ & 0.125 & $\mathrm{p}<0.1$ & 0.45 \\
\hline IST $>$ CFP & 0.329 & $\mathrm{p}<0.001$ & 0.53 \\
\hline IST > ECI & 0.611 & $\mathrm{p}<0.001$ & 0.45 \\
\hline $\mathrm{ECI}>\mathrm{CFP}$ & 0.406 & $\mathrm{p}<0.001$ & 0.53 \\
\hline PANEL C: & Indirect Effect & Probability & Decision \\
\hline \multicolumn{4}{|l|}{ Panel B: Indirect Effects } \\
\hline $\mathrm{EOC}>\mathrm{ECI}>\mathrm{CFP}$ & 0.051 & $\mathrm{p}<0.05 * *$ & $\mathrm{H}_{1}$ is supported \\
\hline $\mathrm{EOC}>\mathrm{IST}>\mathrm{CFP}$ & 0.136 & $\mathrm{p}<0.001 * * *$ & $\mathrm{H}_{2}$ is supported \\
\hline $\mathrm{EOC}>\mathrm{IST}>\mathrm{ECI}>\mathrm{CFP}$ & 0.102 & $\mathrm{P}<0.05 * *$ & $\mathrm{H}_{3}$ is supported \\
\hline
\end{tabular}

\section{Discussion}

When the first hypothesis is supported, it means that this study has provided empirical evidence of the mechanism on how eco-oriented culture affects corporate performance through eco-oriented continuous improvement. The finding of descriptive statistics suggests that managers have a high commitment in achieving a good financial performance. This issue is understood because the company's financial performance greatly affects their financial condition as employees. Furthermore, managers feel the need to make continuous improvements in their business processes, especially in producing environmentally friendly products and Green products which are needed to meet the expectations of consumers who are increasingly concerned about the environmental issues. The low highly rating of eco-oriented culture by managers suggests that the implementation of organizational culture which includes the environmental issues is not strong enough at the SOEs and its subsidiaries in Indonesia. This explains why Indonesia still faces vast environmental problems. It is suggested that the management of the SOEs and its subsidiaries build a strong eco-oriented culture in order to take advantage of the coming of the green consumers era and the threat of eco-oriented competitors. Eco-oriented culture and eco-oriented continuous improvement can be used as the source of competitive advantage to face the global competitors starting to flood the Indonesian market. 


\section{ENTREPRENEURSHIP AND SUSTAINABILITY ISSUES}

ISSN 2345-0282 (online) http://jssidoi.org/jesi/

2020 Volume 8 Number 2 (December)

http://doi.org/10.9770/jesi.2020.8.2(20)

Make your research more visible, join the Twitter account of ENTREPRENEURSHIP AND SUSTAINABILITY ISSUES: @Entrepr69728810

The low highly ratings of eco-oriented culture also suggests that managers of the SOEs and subsidiaries in Indonesia have a relatively above-average concern on the importance of eco-oriented culture in relation to ecooriented continuous improvement and financial performance. They view that culture is important for improving the business processes and the financial success of their company. They realize that having an organizational culture which includes environmental concerns is crucial to building habits in the daily management activities. Although now they don't have a strong eco-oriented culture, managers tend to perceive that culture will drive their company to continuously make improvements in environmentally friendly products and programs in order to achieve financial success. This result concludes the path that the stronger the eco-oriented culture, the better is the eco-oriented continuous improvement, and then the better is the corporate financial performance. This finding supports and extends the results of the previous studies by Jabnoun (2001), Zehir et al. (2011), Chatterjee et al. (2018), and Chen (2018).

The second path to excellent corporate financial performance is to have a good understanding of the mechanism on how innovation strategy affects corporate financial performance through eco-oriented continuous improvement. The moderate rating of innovation strategy reflects that the managers of the SOEs and their subsidiaries in Indonesia have above-average concerns on the importance of innovation as strategy. This finding suggests that managers feel the need for their company to have an innovation strategy as a means to deal with the dynamics of a rapidly changing business environment. Good innovations in environmentally friendly products and programs will guarantee the continuity of the company. The company may become the first mover as the green innovator and enjoy its competitive advantage position. The innovation capability must be continously executed in the daily business processes, and then it will lead to customer satisfaction and financial success. This finding is in line with the results of the previous studies by Nybakk and Jenssen (2012), Karabulut (2015), and Chuan and Lin (2017).

Finally, the third path to excellent corporate financial performance can be achieved by understanding the mechanism of how to use both innovation strategy and eco-oriented continuous improvement in the relationship between eco-oriented culture and financial performance. As stated by Kaplan and Norton (2004), excellent financial performance needs revenue strategy and cost strategy. Every manager understands that revenue improvements can be achieved through delivering the right value proposition to customers, including ecoawareness or green customers. Then, the managers will align their business processes, especially customer management processes and operation management processes to meet the eco-oriented customers and always continuously make improvements. To generate a good internal business process, the managers need the readiness of human capital, information capital and organization capital (M. Chen, 2005; Kaplan \& Norton, 2005). Culture is one strategic element in organization capital that provides a foundation for members of the organization to work with a trusted management philosophy (Posner, Kouzes, \& Schmidt, 1985). Without the presence of a strong organizational culture, the company does not have a solid foundation in developing and executing innovation strategies as well as making continuous improvements so that it will be difficult to achieve a good financial performance. The understanding of the third path to excellent corporate financial performance in the era of green stakeholders, including customers and green competitors is crucial for managers, including the managers of the SOEs and their subsidiaries in Indonesia. This result supports and expands the results of previous studies by Bapst (1994); Calantone et al. (2002); Kaasa (2017); Rafailidis et al. (2017); and Prim et al. (2017). 


\section{ENTREPRENEURSHIP AND SUSTAINABILITY ISSUES}

ISSN 2345-0282 (online) http://jssidoi.org/jesi/

2020 Volume 8 Number 2 (December)

http://doi.org/10.9770/jesi.2020.8.2(20)

Make your research more visible, join the Twitter account of ENTREPRENEURSHIP AND SUSTAINABILITY ISSUES: @Entrepr69728810

\section{Conclusions}

Many previous studies have been conducted to find evidence of the direct impact of organizational culture or strategies or continuous improvement on financial performance (Cox, Friedman, \& Tribunella, 2011; Hillestad, Xie, Haugland, \& Hillestad, 2010; Posner, Kouzes, \& Schmidt, 1985). However, very rarely are studies conducted to seek the mediating effect of innovation strategy and continuous improvement on the culturefinancial performance relationship, especially in the context of environmental awareness (eco-orientation) and in a developing country (Soewarno, Tjahjadi, \& Fithrianti, 2019).

Using a sample of 103 SOEs managers, this study has provided empirical evidence of the resource-based view (RBV). This study employs a variance-based or partial least squares structural equation modeling to test the hypotheses. The results show the following. Firstly, this study proves that eco-oriented continuous improvement partially mediates the relationship between eco-oriented culture and corporate financial performance. Secondly, this study confirms that eco-oriented continuous improvement partially mediates the relationship between innovation strategy and corporate financial performance. Thirdly, this study also proves that eco-oriented continuous improvement and innovation strategy partially mediate the relationship between eco-oriented culture and corporate financial performance.

This study makes an original contribution in terms of seeking the mediating effects, building a more comprehensive model, focusing on eco-orientation and setting research in a developing country. The results help managers to understand the importance of eco-orientation and awareness in their company and how to use it in achieving a better performance. This implies that managers of the SOEs need to build a strong eco-oriented culture, to develop and execute innovation strategy, to implement that culture and innovation in continuous process improvements, so that it will drive financial performance. This encourages managers to have a more comprehensive and holistic understanding of a value creation process.

This study has the following limitations: Firstly, this research is conducted in Indonesia and uses managers of the SOEs and their subsidiaries as sample, therefore it limits the generalization. To improve the generalization, future research must be conducted in other countries with different cultures and regulations as well as managers in publicly listed companies. Secondly, using questionnaires to obtain data from the managers' perception may raise the issue of cognitive bias. In the future, researchers can use secondary data even though this is also difficult due to the issue of proxies and measurements as well as confidential data gathering. Thirdly, in terms of the analysis method, this study employs a partial least squares (PLS) structural equation modeling. It raises the issue of causality, and therefore a future study could employ other approaches such as experimentation. The model and hypotheses of this study can still be used by future researchers with the addition of other variables such as eco-oriented creativity and legitimacy.

\section{References}

Ahmed, N.U., Montagno, R.V, \& Firenze, R.J. 1998. Organizational performance and environmental consciousness : an empirical study. Management Decision 36(2): 57-62. https://doi.org/10.1108/00251749810204124

Akhlagh, E. M., Moradi, M., Mehdizade, M., \& Ahmadi N. D. 2013. Innovation strategies, performance diversity and development: An empirical analysis in Iran construction and housing industry. Iranian Journal of Management Studies 6(2): 31-60. https://doi.org/10.22059/IJMS.2013.32063 


\section{ENTREPRENEURSHIP AND SUSTAINABILITY ISSUES}

ISSN 2345-0282 (online) http://jssidoi.org/jesi/

2020 Volume 8 Number 2 (December)

http://doi.org/10.9770/jesi.2020.8.2(20)

Make your research more visible, join the Twitter account of ENTREPRENEURSHIP AND SUSTAINABILITY ISSUES: @Entrepr69728810

Akman, G. \& Yilmaz, C. 2008. Innovative capability, innovation strategy and market orientation: An empirical analysis in Turkish software industry. International Journal of Innovation Management 12 (1): 69-111. https://doi.org/10.1142/S1363919608001923

Alisjahbana. A.S \& Busc, J.M. 2017. Forestry, Forest Fires, and Climate Change in Indonesia. Bulletin of Indonesian Economic Studies 53(2): 111-136. https://doi.org/10.1080/00074918.2017.1365404

Baldassarre, B., Schepers, M., Bocken, N., Cuppen, E., \& Calabretta, G. (2019). Industrial Symbiosis : towards a design process for ecoindustrial clusters by integrating Circular Economy and Industrial Industrial Ecology perspectives. Journal of Cleaner Production. https://doi.org/10.1016/j.jclepro.2019.01.091

Bapst, G. 1994. Lightning Strategies for Innovation, Update on Excellence, March/April 1994. Retrieved from http://www.ame.org/sites/default/files/target_articles/94q2u4.pdf

Baron, R.M. \& Kenny, D.A. 1986. The moderator-mediatorvariable distinction in social psychological research: conceptual, strategic and statistical considerations. Journal of Personality and Psychology 51: 1173-1182. https://doi.org/10.1037//0022-3514.51.6.1173

Calantone, R. J., Cavusgil, S. T., \& Zhao, Y. 2002. Learning orientation, firm innovation capability, and firm performance. Industrial Marketing Management, 31: 515-524. https://doi.org/10.1016/S0019-8501(01)00203-6

Cetindamar, D. \& Husoy, K. 2007. Corporate social responsibility practices and environmentally responsible behavior: The case of the United Nations global compact. Journal of Business Ethics 76(2): 163-176. https://doi.org/10.1007/s10551-006-9265-4

Chatterjee, A., Pereira, A. \& Bates, R. 2018. Impact of individual perception of organizational culture on the learning transfer environment. International Journal of Training and Development, 22(1): 15-33. https://doi.org/10.1111/ijtd.12116

Chen, C., Lee, S., \& Stevenson, H.W. 1995. Response Style and Cross-Curtural Comparisons of Rating Scales among East Asians and North American Students. Psychological Science 6(3). https://doi.org/10.1111/j.1467-9280.1995.tb00327.x

Chen, H.L. 2018. Supply chain risk's impact on corporate financial performance. International Journal of Operations \& Production Management 38(3):713-731. https://doi.org/10.1108/IJOPM-02-2016-0060

Chen, M. 2005. An empirical investigation of the relationship between intellectual capital and firms' market value and financial performance. 6(2): 159-176. https://doi.org/10.1108/14691930510592771

Chertow, M. R. (2000). Industrial Symbiosis: Literature and Taxonomy. Annual Review of Energy and the Environment, $25,313-337$.

Chertow, M. R. (2007). “Uncovering” Industrial Symbiosis. Journal of Industrial Ecology, 11(1).

Chin, W.W. 1998. The partial least squares approach to structural equation modeling. In G. A. Marcoulides (Ed.), Modern methods for business research, London: Lawrence Erlbaum Associates.

Chin, W.W. 1998. Issues and opinion on structural equation modeling. MIS Quarterly: Management Information Systems 22(1). Retrieved from https://www.researchgate.net/publication/220260360 Issues and Opinion on Structural Equation Modeling/references

Chin, W.W. \& Newsted, P.R. 1999. Structural modelling analysis with small samples using partial least squares In R.H. Hoyle (Ed.) Statistical strategies for small sample research. Thosand Oaks: Sage Publications.

Chitsaz, E., Tajpour, M., Hosseini, E., Khorram, H., \& Zorrieh, S. (2019). The effect of human and social capital on entrepreneurial activities: a case study of Irand and implications. Entrepreneurship and Sustainability Issues, 6(3), 1393-1403.

Coulmont, M., Lambert, K., \& Berthelot, S. 2018. National culture and UN global compact affiliation. Social Responsibility Journal 14(3): 584-600. https://doi.org/10.1108/SRJ-09-2016-0155

Cox, P. L., Friedman, B.A., \& Tribunella, T. 2011. Relationships among Cultural Dimensions, National Gross Domestic Product, and Environmental Sustainability. Journal of Applied Business and Economics 12(6): 46-56. Retrieved from http://citeseerx.ist.psu.edu/viewdoc/download?doi=10.1.1.1031.7959\&rep=rep1\&type=pdf 


\section{ENTREPRENEURSHIP AND SUSTAINABILITY ISSUES}

ISSN 2345-0282 (online) http://jssidoi.org/jesi/

2020 Volume 8 Number 2 (December)

http://doi.org/10.9770/jesi.2020.8.2(20)

Make your research more visible, join the Twitter account of ENTREPRENEURSHIP AND SUSTAINABILITY ISSUES: @Entrepr69728810

Ferreira, L.M., Silva, C., \& Azevedo, S.G. 2016. An environmental balanced scorecard for supply chain performance measurement. Benchmarking: An International Journal 23(6): 1398-1422. https://doi.org/10.1108/BIJ-08-2013-0087

Fornell, C. \& Larcker, D.F. 1981. Structural Equation Models with Unobservable Variables and Measurement Error: Algebra and Statistics. Journal of Marketing Research 18(3): 382. https://doi.org/10.2307/3150980

Hair, J. F., Risher, J. J., Sarstedt, M. \& Ringle, C. M. 2018. When to use and how to report the results of PLS-SEM. European Business 31(1). https://doi.org/10.1108/EBR-11-2018-0203

Hansen, E., Dibrell, C., \& Down, J. 2006. Market Orientation, Strategy, and Performance in the Primary Forest Industry. Forest Science, 52(3): $209 . \quad$ Retrieved from https://www.researchgate.net/publication/233585754_Market_Orientation_Strategy_and_Performance_in_the_Primary_Forest_Industry

Herlina, E., Syarifudin, D., \& Kartika, R. 2019. The Local Knowledge Transfer Based on Continuous. Journal of Management Review, $3(1), 277-284$.

Hillestad, T., Xie, C., Haugland, S. A., \& Hillestad, T. 2010. Innovative corporate social responsibility: the founder' s role in creating a trustworthy corporate brand through "green innovation". Journal of Product \& Brand Management 19(6): 440-451. https://doi.org/10.1108/10610421011085758

Hulland, J. 1999. Use of Partial Least Squares (PLS) in strategic management research: a review of four recent studies. Strategic Management Journal 20(2): 195-204. Retrieved from https://www.jstor.org/stable/3094025?seq=1\#metadata_info_tab_contents

Husted, B. W. 2005. A Cross-National Study of the Determinants of Environmental Sustainability. Journal of Chemical Information and Modeling, 45(3): 349-371. https://doi.org/10.1017/CBO9781107415324.004

Indonesia Investment. 2019, April 09. Environmental Pollution: Indonesia's Battle against Plastic Waste: March 2019 Edition. Indonesia Investment. Retrieved from https://www.indonesia-investments.com/id/news/todays-headlines/environmental-pollution-indonesia-s-battleagainst-plastic-waste/item9110?

Jabnoun, N. 2001. Values underlying continuous improvement, The TQM Magazine 13(6): 381. https://doi.org/10.1108/09544780110406137

Kaasa, A. 2017. Culture and Innovation: Evidence from the European Union and Neighbouring Countries. Journal of Economic and Social Geography, 108(1): 109-128. https://doi.org/10.1111/tesg.12194

Kaplan, R. S. \& Norton, D.P. 2005. The strategy map: guide to aligning intangible assets. Strategy \& Leadership, 32(2004): 10-17. https://doi.org/10.1108/10878570410699825

Kaplan, R.S. \& Norton, D. P. 2004. Strategy Maps: Converting Intangible Assets into Tangible Outcomes. Harvard Business School Press: Boston, MA.

Karabulut, A.T. (2015). Effects of Innovation Strategy on Firm Performance: A Study Conducted on Manufacturing Firms in Turkey. Procedia - Social and Behavioral Sciences, 195: 1338 - 1347. https://doi.org/10.1016/j.sbspro.2015.06.314

Ketola, T. (2009). Pre-Morphean Paradigm - An Alternative to Modern and Post-Modern Paradigms of Corporate Sustainability. Sustainable Development 17: 114-126. https://doi.org/10.1002/sd.406

Kim, S. T., \& Lee, S. Y. (2012). Stakeholder pressure and the adoption of environmental logistics practices: Is eco-oriented culture a missing link?. The International Journal of Logistics Management, 23(2): 238-258. https://doi.org/10.1108/09574091211265378

Kim, W.C. \& Mauborgne, R. 2005. Blue Ocean Strategy: How to Create Uncontested Market Space and Make Competition Irrelevant. HBS Press.

Kim, W.C. \& Mauborgne, R. 2017. Blue Ocean Shift: Beyond Competing - Proven Steps to Inspire Confidence and Seize New Growth. Hachette Book: New York 


\section{ENTREPRENEURSHIP AND SUSTAINABILITY ISSUES}

ISSN 2345-0282 (online) http://jssidoi.org/jesi/

2020 Volume 8 Number 2 (December)

http://doi.org/10.9770/jesi.2020.8.2(20)

Make your research more visible, join the Twitter account of ENTREPRENEURSHIP AND SUSTAINABILITY ISSUES: @Entrepr69728810

Klassen, R.D. 2006. Exploring the linkage between investment in manufacturing and environmental. International Journal of Operations \& Production Management 20(2): 127-147. https://doi.org/10.1108/01443570010304224

Kwak, D.W., Seo, Y.J. \& Mason, R. 2018. Investigating the relationship between supply chain innovation, risk management capabilities and competitive advantage in global supply chains. International Journal of Operations \& Production Management, 38(1): 2-21. https://doi.org/10.1108/IJOPM-06-2015-0390

Kwon, H. \& Lee, J. 2019. Exploring the differential impact of environmental sustainability , operational efficiency, and corporate reputation on market valuation in high-tech-oriented firms. International Journal of Production Economics 211(January): 1-14. https://doi.org/10.1016/j.ijpe.2019.01.034

Leavy, B. 2018.Value innovation and how to successfully incubate "blue ocean" initiatives. Strategy \& Leadership 46(3):1020. https://doi.org/10.1108/SL-02-2018-0020

Lee, H. 2004. The role of competence-based trust and organizational identification in continuous improvement. Journal of Managerial Psychology, 19(6): 623. https://doi.org/10.1108/02683940410551525

Lehtonen, M. 2004. The environmental - social interface of sustainable development: capabilities, social capital , institutions. Ecological Economics, 49: 199-214. https://doi.org/10.1016/j.ecolecon.2004.03.019

Margono, B.A., Potapov, P.V., Turubanova, S., Stolle, F. and Hansen, M.C. 2014. Primary Forest Cover Loss in Indonesia 20002012. Nature Climate Change, 4: 730-735. Retrieved from https://www.nature.com/articles/nclimate2277

Mattera, M. \& Baena, V. 2015. The key to carving out a high corporate reputation based on innovation: corporate social responsibility. Social Responsibility Journal 11(2); 221-241. https://doi.org/10.1108/SRJ$\underline{03-2013-0035}$

Melo, T. 2012. Determinants of corporate social performance: the influence of organizational culture, management tenure and financial performance. Social Responsibility Journal, 8(1): 33-47. https://doi.org/10.1108/17471111211196557

Miles, M.P. \& Munilla, L.S. 1993. The Eco-orientation: An Emerging Business Philosophy?. Journal of Marketing Theory and Practice, 1(2): 43-51. Retrieved from https://www.researchgate.net/publication/285013439 Eco-orientation An emerging business philosophy

Nason, R.S. \& Wiklund, J. 2018. An Assessment of Resource-Based Theorizing on Firm Growth and Suggestions for the Future. Journal of Management 44(1); 32-60. https://doi.org/10.1177/0149206315610635

Nazarian, A. Atkinson, P. \& Foroudi, P. 2017. Influence of national culture and balanced organizational culture on the hotel industry's performance. International Journal of Hospitality Management, 63: 22-32. https://doi.org/10.1016/j.ijhm.2017.01.003

Nitzl, C. 2016. The use of partial least squares structural equation modelling (PLS-SEM) in management accounting research: Directions for future theory development. Journal of Accounting Literature, 37: 19-35. https://doi.org/10.1016/j.acclit.2016.09.003

Nunnaly, J.C. 1967. Psychometric theory. New York: McGraw-Hill.

Nybakk, E. \& Jenssen, J.I. 2012. Innovation Strategy, Working Climate, and Financial Performance in Traditional Manufacturing Firms: An Empirical Analysis. International Journal of Innovation Management, 16(2). https://doi.org/10.1142/S1363919611003374

Nybakk, E., Crespell, P., \& Hansen, E. 2011. Climate for Innovation and Innovation Strategy as Drivers for Success in the Wood Industry: Moderation Effects of Firm Size, Industry Sector, and Country of Operation. Silva Fennica, 45(3): 415-430. https://doi.org/10.14214/sf.110

Ogbonna, E. \& Harris, L.C. 2000. Leadership style, organizational culture and performance: empirical evidence from UK companies. The International Journal of Human Resource Management, 11(4): 766-88. https://doi.org/10.1080/09585190050075114

Olson, E.M., Slater, S.F., G. Tomas M.Hult. G.T.M. \& Olson, K.M. 2018. The application of human resource management policies within the marketing organization: The impact on business and marketing strategy implementation, Industrial Marketing Management, 69: 62-73. https://doi.org/10.1016/j.indmarman.2018.01.029 


\section{ENTREPRENEURSHIP AND SUSTAINABILITY ISSUES}

ISSN 2345-0282 (online) http://jssidoi.org/jesi/

2020 Volume 8 Number 2 (December)

http://doi.org/10.9770/jesi.2020.8.2(20)

Make your research more visible, join the Twitter account of ENTREPRENEURSHIP AND SUSTAINABILITY ISSUES: @Entrepr69728810

Orsato, R. J. 2009. When does it pay to be green? In Orsato, R.J. Sustainability Strategies, London: Palgrave Macmillan, 3-22. https://doi.org/10.1057/9780230236851

Pogodina, T. V., Aleksakhina, V. G., Burenin, V. A., Polianova, N., \& Yunusov, L. A. (2019). Towards the innovation-focused industry development in a climate of digitalization: the case of Russia. Entrepreneurship and Sustainability Issues 6(4): $1897-1906$.

Posner, B. Z., Kouzes, J. M. \& Schmidt, W. H. 1985. Shared Values Make a Difference: An Empirical Test of Corporate Culture. Human Resource Management, 24(3): 293-309. https://doi.org/10.1002/hrm.3930240305

Prim, A.L., Filho, L.S., Zamur, L.S.F \& Di Serio, L.Z. 2017. The relationship between national culture dimensions and degree of innovation. International Journal of Innovation Management 21(01): 1730001-1700022. https://doi.org/10.1142/S136391961730001X

Rafailidis, A., Trivellas, P. \& Polychroniou, P. 2017. The mediating role of quality on the relationship between cultural ambidexterity and innovation performance. Total Quality Management \& Business Excellence, 28 (9-10): 1134-1148. https://doi.org/10.1080/14783363.2017.1309122

Rottig, D. \& Reus, T.H. 2018. Research on Culture and International Acquisition Performance: A Critical Evaluation and New Directions. International Studies of Management \& Organization, 48(1): 3-42. https://doi.org/10.1080/00208825.2018.1407082

Sacirovic, S., Ketin, S. \& Vignjevic, N. 2018. Eco-industrial zones in the context of sustainability development of urban areas. Environmental Science and Pollution Research, 26(24): 24346-24356. https://doi.org/10.1007/s11356-018-1390-y

Sheehan, N.T. \& Foss, N.J. 2009. Exploring the roots of Porter's activity-based view. Journal of Strategy and Management, 2(3): 240-260. https://doi.org/10.1108/17554250910982480

Sheth, J.N., Sethia, N.K., and Srinivas, S. 2011. Mindful consumption: a curtomer-centric approach to sustainability. Journal of the Academy Marketing Science, 39: 21-39. https://doi.org/10.1007/s11747-010-0216-3

Soewarno, N., Tjahjadi, B., \& Fithrianti, F. 2019. Green innovation strategy and green innovation The roles of green organizational identity and. Management Decision. https://doi.org/10.1108/MD-05-2018-0563

Stone, G. \& Wakefield, K.L. 2000. Eco-orientation: an extension of market orientation in an environmental context. Journal of Marketing Theory and Practice 8(3): 21-31. https://doi.org/10.1080/10696679.2000.11501872

Stone, G., Joseph, M., \& Blodgett, J. 2004. Toward the creation of an eco-oriented corporate culture : a proposed model of internal and external antecedents leading to industrial firm. Journal of Business \& Industrial Marketing, 19(1): 68-84. https://doi.org/10.1108/08858620410516754

Stone, G., Mathew, J., \& Blodgett, J. 2004. Toward the creation of an eco-oriented corporate culture: a proposed model of internal and external antecedents leading to industrial firm eco-orientation. The Journal of Business \& Industrial Marketing, 19 (1): 68. https://doi.org/10.1108/08858620410516754

Tamazian, A., \& Rao, B.B. 2010. Do economic financial and institutional developments matter for environmental degradation ? Evidence from transitional economies. Energy Economics, 32(1): 137-145. https://doi.org/10.1016/j.eneco.2009.04.004

Turubanova, S., Potapov, P.V., Tyukavina, A. \& Hansen, M.C. 2018. Ongoing primary forest loss in Brazil, Democratic Republic of the Congo, and Indonesia, Environment Research Letter, 13(7). https://doi.org/10.1088/1748-9326/aacd1c

Venkatraman, N. 1989. Strategic orientation of business enterprises: The construct, dimensionality, and measurement. Management Science, 35(8): 942-962. Retrieved from https://www.jstor.org/stable/2632149

Wang, C., \& Wang, C. (2019). How organizational green culture influences green performance and competitive advantage The mediating role of green innovation. Journal of Manufacturing Technology. https://doi.org/10.1108/JMTM-09-2018-0314

Wernerfelt, B. 1984. A Resource-Based View of the Firm. Strategic Management Journal 5(2): 171-180. Retrieved from http://links.jstor.org/sici?sici=0143-2095\%28198404\%2F06\%295\%3A2\%3C171\%3AARVOTF\%3E2.0.CO\%3B2-L 
ENTREPRENEURSHIP AND SUSTAINABILITY ISSUES

ISSN 2345-0282 (online) http://jssidoi.org/jesi/

2020 Volume 8 Number 2 (December)

http://doi.org/10.9770/jesi.2020.8.2(20)

Make your research more visible, join the Twitter account of ENTREPRENEURSHIP AND SUSTAINABILITY ISSUES: @Entrepr69728810

Yasar, N. B., Sezen, B., \& Karakadilar, I. S. (2017). Mediating effect of continuous improvement on the relationship between innovation and financial performance. Total Quality Management \& Business Excellence, 1-15. https://doi.org/10.1080/14783363.2017.1353415

Zehir, C., Ertosun. O.G., Zehir, S., \& Muceldili, B. 2011. The Effects of Leadership Styles and Organizational Culture over Firm Performance: Multi-National Companies in Istambul. Procedia - Social and Behavioral Sciences, $24:$ 1460-1474. https://doi.org/10.1016/j.sbspro.2011.09.032

Zhao, H., Teng, H., \& Wu, Q. 2018. The effect of corporate culture on firm performance: Evidence from China. China Journal of Accounting Research 11(1): 1-19. https://doi.org/10.1016/j.cjar.2018.01.003

Zhou, H., Yang, Y., Chen, Y., \& Zhu, J. 2018. Data envelopment analysis application in sustainability: The origins, development and future directions. European Journal of Operational Research 264(1): 1-16. https://doi.org/10.1016/j.ejor.2017.06.023

\section{Appendix}

List of Manufacturing State-owned Enterprises (SOEs):

1. Heavy equipment: PT Boma Bisma Indra

2. Nuclear power: PT Batan Teknologi

3. Industrial machinery: PT Barata Indonesia

4. Pharmaceutical : PT Kimia Farma; PT Bio Farma; PT Indo Farma

5. Explosives: PT Dahana

6. Ship: PT PAL Indonesia; PT Dok dan Perkapalan Surabaya

7. $\quad$ Salt producer: PT Garam

8. $\quad$ Glass producer: PT Industri Gelas

9. $\quad$ Fertilizer: PT Pupuk Indonesia Holding

10. Fabric manufacturer: PT Cambrics Premissima

11. Steel: PT Krakatau Steel

12. Cement: PT Semen Indonesia; PT Semen Baturaja

Noorlailie SOEWARNO is the Doctor of Accounting at Faculty of Economics and Business Universitas Airlangga, Surabaya, Indonesia. She has been teaching accounting for more than 20 years. Her research interest including management accounting, strategic management, and performance management.

ORCID ID: https://orcid.org/0000-0003-2134-2125

Bambang TJAHJADI is the Professor of Accounting at Faculty of Economics and Business Universitas Airlangga, Surabaya, Indonesia. He has been teaching accounting for more than 30 years. His research interest including management accounting, strategic management, and performance management. Bambang is a member of professional organization such as Certified Professional Marketers and Certified Management Accountant.

ORCID ID: https://orcid.org/0000-0002-9781-729X https://orcid.org/0000-0003-2134-2125

Copyright (C) 2020 by author(s) and VsI Entrepreneurship and Sustainability Center

This work is licensed under the Creative Commons Attribution International License (CC BY).

http://creativecommons.org/licenses/by/4.0/

(c) (7) Open Access 